Archives of Agriculture and Environmental Science

\title{
Effect of genotype on proximate composition and biological yield of maize (Zea mays L.)
}

\author{
Sayed Hasanul Kabir ${ }^{1}$, Ashim Kumar Das ${ }^{2^{*}}$ iD , Md. Sadiqur Rahman ${ }^{3}$, Samiron Kumar Singh ${ }^{4}$, \\ Monjur Morshed ${ }^{5}$ and Aung Sing Hla Marma ${ }^{6}$
}

${ }^{1}$ Department of Biochemistry, Sher-e-Bangla Agricultural University, Dhaka, BANGLADESH

${ }^{2}$ Department of Agroforestry and Environment, Bangabandhu Sheikh Mujibur Rahman Agricultural University, Gazipur-1706, BANGLADESH

${ }^{3}$ Scientific Officer, Regional Agricultural Research Station, Agricultural Research Institute (BARI), Moulovibazar, BANGLADESH

${ }^{4}$ Department of Biochemistry, Sher-e-Bangla Agricultural University, Dhaka, BANGLADESH

${ }^{5}$ Department of Soil Science, Bangabandhu Sheikh Mujibur Rahman Agricultural University, Gazipur-1706, BANGLADESH

${ }^{6}$ Department of Agronomy, Bangabandhu Sheikh Mujibur Rahman Agricultural University, Gazipur-1706, BANGLADESH

*Corresponding author's E-mail: ashimbsmrau@gmail.com

\section{ARTICLE HISTORY}

Received: 18 April 2019

Revised received: 11 May 2019

Accepted: 22 May 2019

\section{Keywords}

Genotype

Maize (Zea mays L.)

Nutrient and mineral composition

Proximate composition

\begin{abstract}
An experiment was conducted to study the proximate composition of five released maize varieties (Zea mays L.) of Bangladesh Agricultural Research Institute (BARI), which was popularly growing in Bangladesh namely BHM-5, BHM-8, BHM-13, BHM-15, and Barnali. There was none a single variety performed best in all nutrient parameters. Among these maize varieties, the highest grain weight of 100 seeds, and yield was found in BHM-15 (32.84g and 12.6 ton/ha). In the case of proximate analysis, the highest protein, ash, and fat content was recorded from BHM-15 (13.11\%, 2.33\%, and 5.44\%), the highest carbohydrate content was recorded from BHM-13 (82.40\%), and the highest amount of fiber was recorded from BHM-5 (2.07\%). On the other hand, the lowest amount of carbohydrate and protein was recorded from BHM$15(77.67 \%)$ and BHM-8 (10.96\%), respectively. BHM-13 contained the lowest amount of fiber (1.24\%) and fat (4.27\%). Barnali and BHM-15 showed better performance for most of the minerals. The findings concluded that the different genotypes of maize differ substantially in their chemical and mineral compositions.
\end{abstract}

(C)2019 Agriculture and Environmental Science Academy

Citation of this article: Kabir, S.H., Das, A.K., Rahman, M.S., Singh, S.K., Morshed, M. and Marma, A.S.H. (2019). Effect of genotype on proximate composition and biological yield of maize (Zea mays L.). Archives of Agriculture and Environmental Science, 4(2): 185-189, https://dx.doi.org/10.26832/24566632.2019.040209

\section{INTRODUCTION}

Maize (Zea mays L.) is the third most important cereal crop in the world after wheat and rice. Maize literally means that which "sustains life". Pieces of evidence from Botany, Genetics and Cytology have pointed towards a common origin for every existing type of maize $(2 n=20)$. Maize belongs to Family Poaceae and Genus Zea. Maize is a highly crosspollinated species. It was also one of the first plant species identified to photosynthesize by $\mathrm{C} 4$ pathway with high yield potential. The suitability of maize to diverse environments is unmatched by any other crop as the expansion of maize to new areas and environment still continues, as it has a range of plasticity. By origin, it is a tropical crop and has adapted magnificently to temperate environments with much higher productivity. It is grown from latitude $580 \mathrm{~N}$ to $400 \mathrm{~S}$, from sea level to higher than $3000 \mathrm{~m}$ altitude and in areas receiving yearly rainfall of 250 to $5000 \mathrm{~mm}$ (Dowswell et al., 1996; Premlatha and Kalamani, 2010). The United States of America has the largest cultivated area of corn. Major maize producers are the USA (30\%), China (15\%), European Union (14\%), Brazil (4\%) and India (3\%). These five countries have around $60 \%$ of the world's corn harvested area (Annonymous, 2007; Tao Ye et al., 2015).

Maize is used as a basic food ingredient, either in its original or modified form. Maize grains are a rich source of starch (72\%), 
ash (17\%), protein (10.4\%), fiber (2.5\%), oil (4.8\%), vitamins and minerals (Farhad et al., 2009; Zhiqiang et al., 2018). The oil and protein contents have commercial value and are used in food products manufacturing (Paliwal, 2000). Maize is used primarily as a food for humans in most areas of the world, in contrast to the United States where about 85 percent of the crop is used as cattle feed. Maize is used for livestock feeds in a variety of ways. It may be used for grain, silage, hogging down, grazing and forage. Most of the crop in the United States is used for grain. About 40 percent is fed to hogs, followed by cattle (29\%) and poultry (19\%). The mixed feed manufacturing industry is the largest industrial user of shelled grain. Byproducts of processing are gluten feed, gluten meal, oil cake meal, germ meal, distiller's and brewer's grains. About three-fourths of the mixed feed industries output is manufactured poultry and dairy feed. American industries are greatly interested in the starch part of the kernel.

In general, it has a great worldwide significance as human food, animal feed and a source of a large number of industrial products. It has the highest potential of per day carbohydrate productivity. Thus, the father of the green revolution, the renowned Noble Laureate, Dr. Norman E. Borlaug, stated that "After the last two decades saw the revolution in rice and wheat, the next few decades will be known as maize era". A number of genotypes e.g. single crosses, double crosses, threeway crosses, vertical hybrids, multiple hybrids composites, synthetics, pools, populations etc. are feasible to maize growing farmers for commercial cultivation by virtue of the crop being highly cross-pollinated (Tao Ye et al., 2015; Zhiqiang et al., 2018). Though maize is an important crop occupies a huge area in Bangladesh chemical characteristics contributing to yield are not clearly understood. Keeping in view of the above facts the present investigations were undertaken to evaluate the physical and chemical composition of different varieties of maize, to compare the physico-chemical parameters and nutrition quality of different varieties of maize and to identify nutritionally potential maize varieties for the welfare of human being.

\section{MATERIALS AND METHODS}

The experiment was conducted at the Laboratory of Department of Biochemistry, Sher-e-Bangla Agricultural University, Dhaka, Bangladesh; and, oilseed research center and soil science division, BARI, Gazipur, Bangladesh. Five released variety of maize namely Barnali (Evolved by the BARI in 2005 and grain is small in size and yellow in color), BHM-5 (Evolved by the BARI in 2005 and grain is big in size and yellow in color), BHM-8 (Evolved by the BARI in 2005 and grain is big in size and yellow in color), BHM-13 (Evolved by the BARI in 2005 and grain is big in size and white in color), BHM-15 (Evolved by the BARI in 2005 and grain is big in size and yellow in color) were selected for the study. The seeds were collected from Bangladesh Agriculture Research Institute (BARI). Seeds were cleaned, sun-dried and stored into a plastic container in a cool place until used for the chemical analysis (Figure 1).

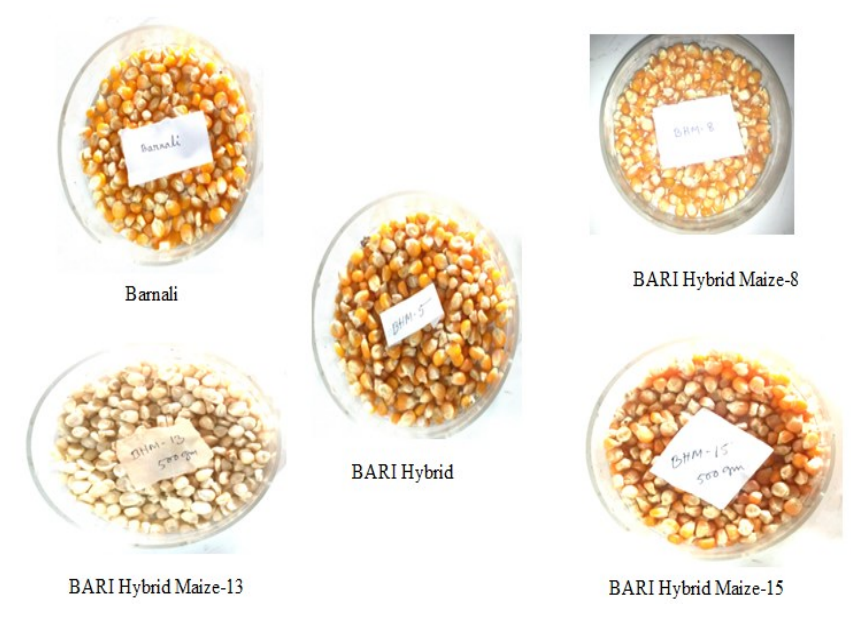

Figure 1. Photograph showing variations in seed coat color, seed size and shape of maize varieties (Z. mays).

\section{Determination of 100 grain seed weight}

The mass was determined by randomly selecting 25 seed samples and weighing in an electronic balance of $0.001 \mathrm{~g}$ sensitivity. The weight was then converted into 100 seed mass.

\section{Determination of moisture}

The moisture content of maize sample was determined by the method of (Ezeagu et al., 2011). The drying, cooling, and weighing were continued repeatedly until a constant weight was obtained by the difference. The weight of the moisture loss was determined and expressed in percentage. The procedure was repeated for samples. It was calculated as shown below:

$$
\text { Moisture }(\%)=\frac{(W 2-W 1)}{(W 2-W 3)} \times 100
$$

\section{Determination of ash}

The sample is ignited at $600^{\circ} \mathrm{C}$ to burn off organic material. The inorganic material which does not volatilize at that temperature is called ash. The procedure was described by Ranganna (1986). It was calculated as shown below:

$$
\text { Ash }(\%)=\frac{\text { Weight of the ash }}{\text { Weight of the sample taken }} \times 100
$$

\section{Chemical analysis}

\section{Estimation of fats}

The fat content of the samples was determined by the continuous solvent extraction using a Soxhlet apparatus by the methods of Hughes (1969) which contains usual lipids including waxed pigments, certain gums, and resins. A better name for these constituents would be "ether soluble extract". It was calculated as shown below:

$$
\begin{aligned}
& \text { Crude fat (on a dry weight) (\%) } \\
& =\frac{\text { Wt. of thimble \& sample before extraction }- \text { Wt of thimble \& sample after extraction }}{\text { Weight of sample before extraction }} \times 100
\end{aligned}
$$


Estimation of total protein content by Micro Kjeldhal method The protein content of foodstuff is obtained by estimating the nitrogen content of the material and multiplying the nitrogen value by 6.25 (according to the fact that nitrogen constitutes on average $16 \%$ of a protein molecule). This is referred to as crude protein content since the non-protein nitrogen (NPN) present in the material is not taken into consideration. The estimation of nitrogen is done by the Kjeldahl method (AOAC, 1984).

$$
\mathrm{N}(\%)=\frac{(14.007) \times(\text { normality of the acid, } 0.02) \times(\mathrm{TV})}{\text { Weight of sample }(\mathrm{mg})} \times 100
$$

Where 14.007 is the equivalent weight of nitrogen

Nitrogen $\%$ is converted into protein by multiplying with a factor 6.25 for cereals and pulses.

\section{Estimation of carbohydrate}

Total carbohydrate estimated by the methods of Raghuramulu et al. (2003). The content of the available carbohydrate was determined by the following equation:

Carbohydrate $=100-\{$ (Moisture + Fat protein + Ash + Oil/Fats $)$ g/100g\}

\section{Estimation of minerals}

\section{Digestion solution}

Concentrated Perchloric acid $(100 \mathrm{ml})$ was added to $500 \mathrm{ml}$ concentrated $\mathrm{HNO}_{3}$ to prepare the nitric-perchloric solution.

Digestion of maize seed sample for determination of $\mathrm{Ca}, \mathrm{Mg}, \mathrm{P}$, $\mathrm{S}, \mathrm{Zn}, \mathrm{Fe}, \mathrm{Cu}, \mathrm{Mn}, \mathrm{Fe}$ and B

\section{Analytical procedure}

Nitric-perchloric solution (1:5) is used for digestion of samples than by using a combination dilute-dispenser, $1 \mathrm{ml}$ aliquot was taken from the filtrate and $19 \mathrm{ml}$ water (dilution 1) was added. The other dilutions were made in the following order. For sulpher (S) determination, $7 \mathrm{ml}$ of the aliquot from dilution 1, 9 $\mathrm{ml}$ of acid seed solution and $4 \mathrm{ml}$ of turbidimetric solution were mixed together thoroughly. It was allowed to stand 20 minutes and not longer than 1 hour. The reading was taken in turbid meter or in colorimeter at $535 \mathrm{~nm}$ using a cuvette with $2 \mathrm{~cm}$ light path. For phosphorous $(\mathrm{P})$, and potassium $(\mathrm{K})$ determina- tion, $1 \mathrm{ml}$ aliquot from dilution $1,9 \mathrm{ml}$ of water and $10 \mathrm{ml}$ of color reagent were mixed together. It was allowed to stand about 20 minutes and reading was taken of the spectrophotometer at 680 $\mathrm{nm}$. For calcium (Ca) and magnesium (Mg) determination, $1 \mathrm{ml}$ aliquot from dilution $1,9 \mathrm{ml}$ of water and $10 \mathrm{ml}$ of $1 \%$ lanthanum solution were mixed together. It was analyzed by AA procedure. For Iron (Fe) and Zinc ( $\mathrm{Zn}$ ) determination, the original filtrate was used to analyze these elements by the AA procedure.

\section{Statistical analysis}

The recorded data for each character from the experiments were analyzed statistically to find out the variation resulting from experimental treatments using $R$ software. The mean for all the treatments was calculated and analysis of variance of characters under the study was performed by $\mathrm{F}$ variance test. The mean differences were evaluated by Least Significance test.

\section{RESULTS AND DISCUSSION}

\section{Biological yields}

The highest weight of 100-grain weight was found in BHM-15 (32.84g) where the lowest weight was found in BHM-13 (26.40g). According to Jha et al. (1979), variation ranged from 10.8 to $25.7 \mathrm{~g}$ in 100 grain weight which might as much as similar. Duncan and Hesketh (1968) observed the variation in plant height of different genotypes in maize ranging from 120 $\mathrm{cm}$ to $300 \mathrm{~cm}$ where highest plant height in BHM-5 $(153.98 \mathrm{~cm})$ and lowest in BHM-13 (146.47 cm). However, Yield of BHM-15 (12.6 ton/ha) showed the highest value where the lowest value was found in Barnali (4.8 ton /ha) which one as similar as reported by Paramasivan et al. (2011) presented in Table 1. Seed deterioration increased when the moisture content is increased. Maize seeds contain above $18 \%$ moisture which may accelerate insect infestation and diseases. The maximum moisture was measured in BHM-5 (13.84\%) and the minimum was recorded in BHM-13 (10.22\%) which is almost similar to Gopalan et al. (1985). On the other hand, Ash reported by Cortéz and WildAltamirano (1972) and Bressani et al. (1958) was more or less similar with BHM-15 (2.33\%) which was the highest value and lowest amount of ash content (1.24\%) showed by BHM-5 followed by BHM-13, Bornali, and BHM-8 (1.67\%,1.68\%,1.70\%). However, BHM-13 contains significantly the highest amount of dry matter (89.78\%) and the lowest amount of dry matter content (86.16\%) was recorded in BHM-5.

Table 1. Weight of 100 seeds, plant height, yield, moisture, ash and dry matter of different maize (Z. mays).

\begin{tabular}{|c|c|c|c|c|c|c|}
\hline $\begin{array}{l}\text { Name of the varieties } \\
\text { (Treatment) }\end{array}$ & $\begin{array}{l}100 \text { seeds } \\
\text { weight }(g)\end{array}$ & Plant height (cm) & Yield (ton/ha) & $\begin{array}{l}\text { Moisture } \\
\text { (\%) }\end{array}$ & Ash (\%) & $\begin{array}{c}\text { Dry matter } \\
(\%)\end{array}$ \\
\hline Bornali & $27.36 b$ & $147.88 c$ & $4.8 \mathrm{e}$ & $11.65 c$ & $1.68 \mathrm{~b}$ & $88.35 c$ \\
\hline BHM-5 & $27.30 b$ & $153.98 a$ & $9.4 d$ & $13.84 a$ & $1.24 \mathrm{c}$ & $86.16 \mathrm{e}$ \\
\hline BHM-8 & $27.32 b$ & $149.47 b$ & $10.6 c$ & $12.06 \mathrm{~b}$ & $1.70 b$ & $87.94 d$ \\
\hline BHM-13 & $26.40 c$ & $146.47 d$ & $11.1 b$ & $10.22 \mathrm{e}$ & $1.67 \mathrm{~b}$ & $89.78 a$ \\
\hline BHM-15 & $32.84 a$ & $146.86 d$ & $12.6 a$ & $11.55 d$ & $2.33 a$ & $88.45 b$ \\
\hline $\operatorname{LSD}_{(0.05)}$ & 0.021 & 0.138 & 0.087 & 0.059 & 0.055 & 0.059 \\
\hline$C V(\%)$ & 13.56 & 18.32 & 2.45 & 0.26 & 1.66 & 0.04 \\
\hline
\end{tabular}

Figure in a column followed by common letter do not differ significantly at $5 \%$ level by DMRT. 
Proximate analysis

\section{Carbohydrate}

Generally, starch, reducing sugar and crude fiber are considered the main components of carbohydrate. Tomov and Min (1995) recorded that grain yield and 100-grain weight were negatively correlated with grain starch in maize lines and hybrids where BHM-13 gave significantly the highest amount of carbohydrate (82.40\%) and BHM-15 contains significantly the lowest amount of carbohydrate (77.67\%) presented in Table 2.

\section{Protein}

Protein content is genetically controlled. The amount of protein has been presented in Table 2 . The results showed that among the different maize varieties $\mathrm{BHM}-15$ contains significantly the highest amount of protein (13.11\%) and BHM-5 contains significantly the lowest amount of protein (9.46\%). Proteins reported by Krishnaveni (1983), Verma et al. (2003), Xiang-ling et al. (2011) were more or less similar with present value.

Fat

Crude fat is one of the most important components of maize grains; improvement in fat content is useful for good human health. In the present study, the highest total means fat content are present in $\mathrm{BHM}-15$ (5.44\%) and $\mathrm{BHM}-13$ contains significantly the lowest amount of fat (4.027\%) as similar to Xiang-ling (2011).

\section{Crude fiber}

The crude fiber content of different maize cultivars is varied from $1.24 \%$ to $2.07 \%$ presented in Table 2 . The concentration of protein decreases and the fiber content increases as the plant matures (Vaswani et al., 2016). The significantly highest amount of crude fiber contents were found in BHM-5 (2.07\%) which was followed by the varieties of BHM-8, Bornali, and BHM-15 (1.63\%, 1.60\%, and 1.45\%). Significantly lowest amount of crude fiber content was found in BHM-13 (1.24\%).

\section{Minerals}

The range of Calcium (\%) reported in different maize varieties varied from 2.47 to $3.92 \%$. The Phosphorus (\%) of ranged from 0.30 to $0.39 \%$ which is presented in Table 3 . However, Singh (1976) reported $\mathrm{Ca}$ and $\mathrm{P}$ content (\%) of two maize varieties Ganga-5 $(0.65,0.14)$ and Vijay $(0.47,0.15)$, the difference observed might be due to different cultivars and environmental conditions. The concentration ranges of the micro-minerals $\mathrm{Cu}$, $\mathrm{Fe}, \mathrm{Mn}$, and $\mathrm{Zn}$ were 10.71-13.95 ppm, 57.54-74.52 ppm, 34.6545.89 ppm and 30.51-42.18 ppm respectively. Calcium, copper, zinc and iron were present in appreciable quantities in all the varieties of maize. The main factors affecting the mineral composition of forages are species, variety, stage of maturity, soil and environmental factors, morphological fraction and use of fertilizers etc. On the other hand, minerals content of $\mathrm{Mg}, \mathrm{K}, \mathrm{S}$ and $\mathrm{B}$ were ranged from 1.07-1.42\%, 0.51-0.60\%, 0.02-0.06\% and 11 ppm- 30 ppm, respectively.

Azim et al. (1989) also observed the variation in $\mathrm{Na}, \mathrm{K}, \mathrm{Ca}$ and, $\mathrm{P}$ content of different fractions of the plant. Hussaini et al. (2008) showed that nitrogen fertilizer application up to $60 \mathrm{~kg} / \mathrm{ha} \mathrm{s}$ ignificantly increased the concentration of $\mathrm{N}, \mathrm{P}, \mathrm{Ca}$ and $\mathrm{Mg}$ in maize grain. Zhang et al. (2010) evaluated the effects of genotype and environment on mineral compositions of wheat grains grown in different locations, and found a large variation for all mineral elements. Peterson et al. (1983) also reported significant variation in mineral concentration by genotypes and concluded that the genotype effect was much larger than environment factors.

Table 2. Proximate analysis of protein, fat, crude fiber and carbohydrate of different released and advanced line of maize varieties (Z. mays).

\begin{tabular}{lcccc}
\hline $\begin{array}{l}\text { Name of the varieties } \\
\text { (Treatment) }\end{array}$ & $\begin{array}{c}\text { Carbohydrate } \\
\text { (\%) }\end{array}$ & $\begin{array}{c}\text { Protein } \\
\text { (\%) }\end{array}$ & $\begin{array}{c}\text { Fat } \\
\text { (\%) }\end{array}$ & $\begin{array}{c}\text { Crude fiber } \\
\text { (\%) }\end{array}$ \\
\hline Bornali & $80.05 \mathrm{~d}$ & $11.47 \mathrm{~b}$ & $5.20 \mathrm{~b}$ & $1.60 \mathrm{c}$ \\
BHM-5 & $82.08 \mathrm{~b}$ & $9.46 \mathrm{e}$ & $5.14 \mathrm{~b}$ & $2.07 \mathrm{a}$ \\
BHM-8 & $80.64 \mathrm{c}$ & $10.96 \mathrm{c}$ & $5.07 \mathrm{c}$ & $1.63 \mathrm{~b}$ \\
BHM-13 & $82.40 \mathrm{a}$ & $10.42 \mathrm{~d}$ & $4.27 \mathrm{~d}$ & $1.24 \mathrm{e}$ \\
BHM-15 & $77.67 \mathrm{e}$ & $13.11 \mathrm{a}$ & $5.44 \mathrm{a}$ & $1.45 \mathrm{~d}$ \\
LSD & 0.087 & 0.029 & 0.069 & 0.021 \\
CV(\%) & 0.06 & 0.13 & 0.72 & 0.77 \\
\hline
\end{tabular}

Figure in a column followed by common letter do not differ significantly at $5 \%$ level by DMRT.

Table 3. Proximate analysis of several minerals of different maize varieties (Z. mays).

\begin{tabular}{|c|c|c|c|c|c|c|c|c|c|c|}
\hline $\begin{array}{l}\text { Name of the } \\
\text { varieties } \\
\text { (Treatment) }\end{array}$ & $\begin{array}{l}\mathrm{Ca} \\
(\%)\end{array}$ & $\begin{array}{l}\mathrm{Mg} \\
(\%)\end{array}$ & $\begin{array}{l}P \\
(\%)\end{array}$ & $\begin{array}{l}K \\
\text { (\%) }\end{array}$ & $\begin{array}{c}S \\
(\%)\end{array}$ & $\begin{array}{c}\text { B } \\
(p p m)\end{array}$ & $\underset{(p p m)}{\mathrm{Cu}}$ & $\begin{array}{c}\text { Fe } \\
(p p m)\end{array}$ & $\underset{(p p m)}{M n}$ & $\begin{array}{c}\mathrm{Zn} \\
(\mathrm{ppm})\end{array}$ \\
\hline Bornali & $2.47 d$ & $1.07 d$ & $0.39 a$ & $0.56 \mathrm{~b}$ & $0.02 d$ & $30.00 a$ & $10.71 \mathrm{e}$ & $57.54 \mathrm{e}$ & $34.65 \mathrm{e}$ & $42.18 a$ \\
\hline BHM-5 & $3.19 c$ & $1.23 b c$ & $0.36 b$ & $0.51 \mathrm{e}$ & $0.03 c$ & $19.00 \mathrm{~b}$ & $12.51 \mathrm{c}$ & $67.44 d$ & $40.63 d$ & $40.40 \mathrm{~b}$ \\
\hline BHM-8 & $3.23 c$ & $1.28 \mathrm{~b}$ & $0.34 c$ & $0.54 d$ & $0.04 b$ & $16.00 \mathrm{~b}$ & $12.43 d$ & $72.34 b$ & $41.96 c$ & $32.63 d$ \\
\hline BHM-13 & $3.39 b$ & $1.21 \mathrm{c}$ & $0.30 \mathrm{e}$ & $0.55 c$ & $0.06 a$ & $11.00 \mathrm{c}$ & $12.62 b$ & $70.33 c$ & $42.56 b$ & $34.14 c$ \\
\hline BHM-15 & $3.92 a$ & $1.42 \mathrm{a}$ & $0.32 d$ & $0.60 a$ & $0.04 b$ & $17.33 b$ & $13.95 a$ & $74.52 \mathrm{a}$ & $45.89 a$ & $30.51 \mathrm{e}$ \\
\hline $\operatorname{LSD}_{(0.05)}$ & 0.066 & 0.069 & 0.006 & 0.006 & 0.006 & 3.27 & 0.055 & 0.055 & 0.029 & 0.075 \\
\hline $\mathrm{CV}(\%)$ & 1.1 & 2.97 & 1.13 & 0.12 & 6.19 & 9.30 & 0.24 & 0.04 & 0.04 & 0.11 \\
\hline
\end{tabular}

Figure in a column followed by common letter do not differ significantly at $5 \%$ level by DMRT. 


\section{Conclusion}

From the above results, it was observed that none of the variety of maize performed the best by all nutrient parameters. BHM13 could be considered better for carbohydrate. BHM-15 and BHM-5 performed well results in protein and fiber contents. In case of minerals, most of the varieties contained the higher amount of minerals than the reference rate due to change of fertilizer application rate and as well as soil properties of the different maize growing area. Different varieties viz., Barnali and $\mathrm{BHM}-15$ showed better performance for most of the minerals. Farmers are cultivating maize in their field for the consumption as feed, fodder as well as public consumption. Based on the information mentioned above, it may be concluded that Barnali, $\mathrm{BHM}-5, \mathrm{BHM}-13$, and BHM-15 can be grown in large scale as they contained the highest amount of different nutrient contents. These results will be useful to know about the nutritional properties of the local maize varieties and may guide us in designing strategies that maximize the utility of maize germplasm.

Open Access: This is an open access article distributed under the terms of the Creative Commons Attribution 4.0 License, which permits unrestricted use, distribution, and reproduction in any medium, provided the original author(s) if the sources are credited.

\section{REFERENCES}

Annonymous (2007). World Agricultural Production, Foreign Agricultural Service, Circular series. WAP, 06-07.

AOAC (1984). Official method of analysis of the association of official Agriculture Chemist, 14th edition, Washington D.C.

Azim, A., Naseer, Z. and Ali, A. (1989). Nutritional evaluation of maize fodder at two different vegetative stages. Asian-Australasian Journal of Animal Sciences, 2(1): 27-34, https://doi.org/10.5713/ajas.1989.27

Bressani, R., Paz, Y. Paz, R. and Scrimshaw, N.S. (1958). Corn nutrient losses, chemical changes in corn during preparation of tortillas. Journal of Agricultural and Food Chemistry, 6(10): 770-774.

Cortéz, A. and Wild-Altamirano, C. (1972). Nutritional Improvement of Maize.

Dowswell, C.R., Paliwal, R.L. and Cantrell, R.P. (1996). Maize in the third world. Westview Pres Division of Harper Collins Publishers.

Duncan, W. G. and Hesketh, J. D. (1968). Net photosynthetic rates, relative leaf growth rates, and leaf numbers of 22 races of maize grown at eight temperatures. Crop $\quad$ Science, 670 : https://doi.org/10.2135/cropsci1968.0011183X000800060009x

Ezeagu, I.E., Metges, C.C., Proll, J., Petzke, K.J. and Akinsoyinu, A.O. (1996). Chemical composition and nutritive value of some wild-gathered tropical plant seeds. Food and Nutrition Bulletin, 17(3): 1-4, https://doi.org/10.1177/156482659601700310

Farhad, W., Saleem, M. F., Cheema, M. A. and Hammad, H.M. (2009). Effect of poultry manure levels on the productivity of spring maize (Zea mays L.).
Journal of Animal and Plant Science, 19(3): 122-125.

Gopalan, C., Ramasastri, B.V. and Balasubramanian (1985). Nutritive value of Indian foods. National institute of nutrition, Indian council of medical research, Hyderabad, India.

Hughes, M. (1969). Determination of moisture and oil in the seed of winter rape (Brassica napus) II. Comparison of extraction methods for the estimation of oil. Journal of the Science of Food and Agriculture, 20(12): 745-747, https:// doi.org/10.1002/jsfa.2740201211

Hussaini, M.A., Ogunlela, V.B., Ramalan, A.A. and Falaki, A.M. (2008). Mineral composition of dry season maize (Zea mays L.) in response to varying levels of nitrogen, phosphorus and irrigation at Kadawa, Nigeria. World Journal of Agricultural Sciences, 4(6), 775-780.

Jha, P.K., Kumar, V. and Akhter, S.A. (1979). Variability and association of characters for oil content in maize. Journal of Applied Biology, 7, 1-2.

Krishnaveni, S. (1983). Biochemical constituents of certain promising maize cultures. Madras Agricultural Journal, 70: 139-140.

Paliwal, R.L. (2000). Introduction to maize and its importance. Tropical Maize Improvement and Production (No. CIS-3064. CIMMYT.).

Paramasivan, M., Kumaresan, K. R., Malarvizhi, P., Thiyageswari, S., Mahimairaja, S. and Velayudham, K. (2011). Nutrient optimization strategy for sustainable productivity of hybrid maize (Zea mays L.) in Peelamedu (PIm) series of soils of Tamil Nadu. Research on Crops, 12(1): 33-38.

Peterson, C.J, Johnson, V.A. and Mattern, P.J. (1983). Evaluation of variation in mineral element concentrations in wheat flour and bran of different cultivars. Cereal Chemistry, 60: 450-455.

Premlatha, M. and Kalamani, A. (2010). Correlation studies in maize (Zea mays L.). International Journal of Plant Sciences, 5(1): 376-380.

Raghuramulu, N., Madhavan, N. K. and Kalyanasundaram, S. (2003). A manual of laboratory techniques, National Institute of Nutrition. Indian Council of Medical Research, Hyderabad, India, 56-58.

Ranganna, S. (1986). Handbook of analysis and quality control for fruit and vegetable products. Tata McGraw-Hill Education.

Singh, R. (1976). Voluntary intake, digestibility and efficiency of utilization as influenced by compositional factors. Proceedings: Forage quality evaluation and processing techniques for increased animal productivity (Ed. Pradhan, K. and SS Khirwar), 153-155.

Tao Ye, Wang Lijuan, Liu Kejie, Liu Liyun and Dong Huaiyu (2015). Identification and evaluation of resistance to northern corn leaf blight in maize germplasms. China Plant Protection, 4: 21-24.

Tomov, N. and Min, D.N. (1995). Expression of heterosis in maize. Ratstenier Dni-Nauki, 2791: 20-26.

Vaswani, S., Kumar, R., Kumar, V., Roy, D. and Kumar, M. (2016). Nutritional and mineral composition of different varieties of normal and high quality protein maize fodder at post-cob stage. International Journal of Science, Environment and Technology, 5(5): 2719 - 2727.

Verma, S.S., Luthra, Y.P., Verma, U. and Tomer, R.P.S. (2003). Physiological indices of seed vigour in sorghum (Sorghum bicolor). Indian Journal of Agricultural Science, 73(3): 164-166.

Xiang-ling, L (U), Xin-hai, LI, Yang, CHEN, Zhen-sheng, SHI, Feng-hai, LI and Junfan, FU (2006). Evaluation and identification of resistance to gray leaf spot (GLS) in maize germplasm. Journal of Maize Sciences, 6: 125-128.

Zhang, L.X., Qiang, H., Li, S.Q. and Chen, X.L. (2010). Effects of enhanced atmospheric ammonia on photosynthetic characteristics of two maize (Zea mays L.) cultivars with various nitrogen supply across long-term growth period and their diurnal change patterns. Photosynthetica, 48(3): 389-399, https://doi.org/10.1007/s11099-010-0051-2

Zhiqiang, TIAN, Tangshun, AI, Ce, DENG, Shiting, YOU, Qin, SHI, Yalong, MA, Zhimin, LI and Junqiang, DING (2018). QTL mapping of resistance to northern corn leaf blight in maize inbred line p178 and effect analysis. Journal of Henan Agricultural Sciences, 2: 73-76. 